\title{
Atypical Glandular Cell-Favor Neoplasia
}

National Cancer Institute

\section{Source}

National Cancer Institute. Atypical Glandular Cell-Favor Neoplasia. NCI Thesaurus. Code C141517.

An abnormal endocervical or endometrial cell found in a cervical smear with cytologic features suggestive of a neoplastic process. 